\title{
“Kadın Akademisyen” Olmak: Turizm Alanındaki Kadın Akademisyenlere Yönelik Bir Metafor Çalışması
}

\section{Being "A Woman Academics": A Metaphor Study Aimed at Women Academicians in Tourism Field}

Doç. Dr. V. Rüya EHTIYAR

Akdeniz Üniversitesi

Turizm Fakültesi

E-posta: ehtiyar@akdeniz.edu.tr
Öğr. Gör. Cansu SOLMAZ

Alanya Alaaddin Keykubat Üniversitesi

ALTSO Turizm Meslek Yüksekokulu

E-posta: cansu.solmaz@alanya.edu.tr

Öğr. Gör. Çağla ÜST CAN

Aksaray Üniversitesi

Güzelyurt Meslek Yüksekokulu

E-posta: caglaustcan@aksaray.edu.tr

Öz

Bu çalışmanın amacı, turizm alanında çalışan kadın akademisyenlerin; "kadın akademisyen" olma kavramını zihinlerinde hangi simgelerle betimlediklerini metaforlar aracılığıyla belirlemektir. Çalışmanın araştırma grubunu Türkiye genelinde turizm eğitimi veren üniversitelerde görev yapan kadın akademisyenler oluşturmaktadır. Katılımcılardan kadın akademisyeni herhangi bir şeye benzetmeleri ve neden bu benzetmeyi yaptıklarını açıklamaları istenmiştir. Nitel araştırma deseninin kullanıldığı çalışmada veriler içerik analizi tekniği kullanılarak çözümlenmiştir. En çok metafor üretilen temalar, "mücadele etmesi gereken", "çoklu görevlere sahip" ve "çalışkan biri olarak kadın akademisyen" temaları olmuştur. Diğer temalar ise "zarif", "engellenen", "üretken", "mucizevi bir varlık", "enerjik", "güçlü", "fedakâr", "yol gösterici", "uyum sağlaması gereken" ve "denge sağlaması gereken biri olarak kadın akademisyen" temalarıdır.

Anahtar Kelimeler: Kadın, akademisyen, metafor, turizm.

\section{Abstract}

The aim of this study is to investigate how women academicians working in the field of tourism symbolize the concept of being woman academician in their minds through the metaphors. The research group is women academicians in universities across Turkey in tourism education. Participants were asked to liken women academics to something and explain why they were doing this assimilation. In the study using the qualitative research design, the content analyzed using the content analysis technique. The themes that produced the most metaphors are "the woman academician as someone who has to struggle", "who has multiple tasks", "who is hardworking". Other themes are "the woman academician as someone who is elegant", "blocked", "productive", "supernatural", "energetic", "strong", "devoted", "pathfinder", "who has to suit" and "balance".

Key Words: Woman, academician, metaphor, tourism. 


\section{Giriş}

İnsanlığın ilk dönemlerinden günümüz modern çağına uzanan süreç boyunca kadınlar ev içinde kendilerine yüklenen geleneksel toplumsal roller olan anne ve eş olma rollerini yerine getirirken, aynı zamanda ev dışındaki çeşitli faaliyetlerde kendilerini kanıtlamaya çalışmaktadırlar. İş gücüne dâhil olan ve olmaya çalışan kadınların önünde; toplumsal cinsiyet eşitsizliği, toplumun kültürel yapısının yansımaları, eğitimde fırsat eşitsizliği ve yöneticilik pozisyonlarına yükselememe gibi birtakım engeller bulunmaktadır. Kadın istihdamı, kariyer engelleri, kadın yöneticiliğinin önünde bulunan engeller; sağlıktan bankacılığa kadar farklı sektörlerde çalışan pek çok araştırmacı tarafından incelenen konular olmuştur (Linehan ve Walsh, 1999; Uzun, 2005; Örücü ve diğ., 2007; Karaca, 2007; Taşkın ve Çetin, 2012; Özyer ve Azizoğlu, 2014; Kılıç ve Öztürk, 2014). Bu çalışmanın araştırma grubunu ise Türkiye'deki devlet üniversitelerinde görev yapmakta olan kadın turizm akademisyenleri oluşturmaktadır.

Ülkemizde kadın akademisyenlerle ilgili yapılmış çalışmaların, üniversite yönetiminde kadın akademisyenlerin eksik temsili, kadın akademisyenlerin karşılaştıkları güçlükler, toplumsal cinsiyet algılamaları üzerine yoğunlaştığı görülmektedir (Özkanlı, 2007; Günlük Seven, 2009; Ergöl ve diğ., 2012; Poyraz, 2013; Ünnü ve diğ., 2014; Kahraman ve diğ., 2014; Öztan ve Doğan, 2015; Suğur ve Cangöz, 2016; Yenilmez, 2016; Şentürk, 2016; Şentürk ve diğ., 2017). Bu çalışmada ise kadın turizm akademisyenlerinin metaforlar yoluyla kendilerini bir kadın olarak ve bir akademisyen olarak zihinlerinde nasıl betimlediklerini ortaya çıkarmak amaçlanmıştır.

Hooks' un (1994: 15) da belirttiği gibi, bir şifacı, bir terapist, bir öğretmen ilk önce kendisine yönelmelidir, çünkü eğer O mutsuzsa, diğer insanlara yardım edemez. Small ve diğ. (2011) çalışmalarında, akademisyenlerin ancak bu şekilde öğrenciler ve çalışma arkadaşları arasında karşılıklı olarak yararlı bir ilişki kurabileceğinin altını çizmişlerdir. Dolayısıyla kadın akademisyenlerin kendileri ile ilgili düşüncelerinin ortaya çıkarılması, bir kadın olarak akademisyenliğe atfettikleri imgelerin çözümlenmesi, toplumsal cinsiyet konusunda daha sağlıklı ve doğru düşüncelere sahip bireylerin yetiştirilebilmesi bakımından önemli görülmektedir. Ayrıca turizm alanyazını incelendiğinde turizm alanında çalışan kadın akademisyenler konusunda yabancı çalışmalara rastlanmıştır (Small ve diğ., 2011; Xu ve diğ., 2017; Basurto-Barcia ve Ricaurte-Quijano, 2017; Munar ve diğ., 2015); fakat Türkiye'de doğrudan kadın turizm akademisyenlerini ele alan herhangi bir çalışma bulunmamaktadır. Dolayısıyla çalışmanın hem bu yönü ile hem de niteliksel bir araştırma yöntemi izlemesi bakımından önemli olduğu düşünülmektedir.

\section{Kavramsal Çerçeve}

\subsection{Cinsiyet Eşitsizliği ile İlgili Kuram ve Kavramlar}

Klasik örgüt kuramında cinsiyet eşitsizliği ile ilgili araştırmaların, 1980'li yıllardaki feminist kuram çalışmalarının getirdiği eleştirilere kadar ihmal edildiği görülmektedir (Suğur ve Cangöz, 2016: 91). Feminist kuramın özellikle 1968 sonrası ikinci dalga olarak adlandırılan sürecinde kadınların yaşamlarını ele alan araştırmalar artış göstermiştir. Toplumsal cinsiyet, ataerkillik ve cinsiyet rolleri gibi kavramlardan yararlanılarak cinsiyet eşitsizliği hakkında kuramlar geliştirilmiştir (Özsöz, 2008: 51). Bu kuram bağlamında feminist düşünürler, toplumsal cinsiyet olgusu üzerinden inşa edilen kadın erkek ayrımı ekseninde, kadınların "ötekileştirilerek" ikinci plana atıldıkları bir sistem oluşturulduğunu vurgulamaktadırlar (Emeklier, 2011: 174). 
Macarie ve Moldovan (2012:154) "yönetimin çirkin ördek yavrusu" olarak adlandırdıkları cinsiyet eşitsizliği kavramının nedenlerini açıklamaya çalışan bazı kuramlara değinmiştir (Macarie ve Moldovan, 2012: 154). Bunlardan ilki kalıp yargılar kuramıdır (stereotyping theory). Bu kurama göre, işletmedeki erkeklerin egemen olduğu kadrolarda, terfi kararlarının alınmasında cinsiyet stereotipleri ön plana çıkmaktadır. Erkeklerin rekabetçi, rasyonel, objektif, kabiliyetli, iddialı, aktif, bağımsız ve duygularını kontrol altında tutmaya yetenekli oldukları düşünülürken; kadınların bağımlı, zarif, sıcak, duygusal ve lider özelliklerinden yoksun olarak kodlanması, kadınların üst yönetime yükselememeleri konusunda önemli bir problemdir (Karaca, 2007: 66). İkinci kuram ise atıf kuramıdır (attribution theory). Bu kurama göre; kadınlara yönelik ayrımcı uygulamalar, kadın yöneticiler beklentilerin üstünde veya altında bir başarı gösterdiklerinde belirginleşmektedir. Buna göre bir kadın yönetici, beklenenin üstünde performans gösterdiğinde bu başarı, şans ve benzeri kavramlarla ilişkilendirilmekte, beklenen başarıyı gösteremediğinde ise bu durumda başarısızlık, profesyonel davranmama gibi kişisel özelliklerine dayandırılmaktadır (Macarie ve Moldovan, 2012: 156). Tam aksi yönde erkek yöneticilerde ise üstün başarı; zekâ ve beceri ile düşük performans ise şanssızlık gibi dış faktörlerle açıklanmaktadır. Bir diğer kuram olan eşitlik (equity theory) kuramına göre ise birey, girdilerini (deneyim, eğitim, yetenek) elde ettiği sonuçlarla (ücret düzeyi, terfiler vb.) karşılaştırdığında ortada bir eşitsizlik olduğunu hissediyorsa gerilim meydana gelmektedir (Özkalp ve Kırel, 2001: 331). Bu teoriye dayanarak eğer işveren kadına karşı önyargılı bir tutum içindeyse kadın ve erkek işletmeye aynı katkıyı sunsa dahi kadınların daha az ödüllendirilmesi söz konusu olabilmektedir (Macarie ve Moldovan, 2012: 157).

İlgili alanyazın incelendiğinde yukarıdaki kuramlarla da ilişkili olacak şekilde bahsedilen bir diğer kavram da cam tavan olgusudur. Pek çok yazar tarafından tanım getirilen "cam tavan sendromu"nu genel olarak kadınların yönetim pozisyonlarına gelmelerini engelleyen görünmeyen, şeffaf, kırılmayan birtakım engeller/bariyerler ya da kadınların başarı ve yeteneklerinin göz ardı edilerek yönetim kadrolarından çeşitli sebeplerle uzak tutulmaları olarak tanımlayabilmek mümkündür (Powell ve Butterfiled 1994, Şiyve, 2004:2; Uzun 2005:33).

\section{2. Üniversitelerde Kadın Akademisyenler}

Kadınların yoğunlukla varlık gösterdiği alanlardan biri olan akademiye bakıldığında; akademik alanın toplumsal cinsiyet ve cinsiyet ayrımcılığı tartışmalarının dışında olması beklenmektedir (Karakuş, 2016:534). Fakat çalışmalar akademide de cinsiyet eşitsizliklerinin olduğunu, işyerinde cinsiyetçi dilin kullanımı, karar verici pozisyonların cinsiyet temelinde değerlendirilmesi gibi ayrımcılıklar yaşandığına ilişkin kanıtlar sunmaktadır (Monroe ve diğ.;2008; Small ve diğ., 2011; Munar ve diğ., 2015, Xu ve diğ., 2017). Monroe ve diğ. (2008) özellikle yönetim ve görece daha yüksek gelirli akademik pozisyonlarda cinsiyet eşitsizliğinin yaşandığını vurgulamıştır. Munar ve diğ.'nin (2015) kadın turizm akademisyenleri üzerinde yaptıkları çalışma bulgularına göre akademik dergi editörlerinin sadece \%21'inin kadın olduğu ve çalışma kapsamında incelenen konferansların bilimsel kurullarındaki kadın oranının \%34 olduğu belirtilmiştir.

Yirmi sekiz Avrupa Birliği ülkesinde kadın akademisyenler, akademinin \%40'ını oluştururken, \%20'si üst yönetim pozisyonlarında yer almaktadır. Ülke ülke incelendiğinde Fransa'da \%19, Almanya'da \%17, Belçika'da \%15, Birleşik Krallık 'da $\% 15$ oranında kadın akademisyen üst düzey kadrolarda bulunmaktadır (She Figures, 2016:129). Kanada üniversitelerinde bulunan kadın akademisyen oranının \%40 olduğu, kadın ve erkek profesörler arasında bir ücret ayrımı yaşandığı sonucuna 
ulaşılmıştır. 2015-2016 eğitim yılında Hindistan üniversitelerinde profesör pozisyonunda bulunan kadın akademisyen oranı \%25 iken, Amerika Birleşik Devletleri'nde ise bu oranın \%32 olduğu görülmektedir (www.catalyst.org, 2017). Xu ve diğ.'nin (2017) çalışmalarında Çin'deki üniversitelerde de durumun farklı olmadığı, yönetici pozisyonlarında kadın akademisyen temsilinin düşük olduğu anlaşılmaktadır. 2011-2012 eğitim öğretim yılında Hong Kong'da üst düzey akademik kadrolarda bulunan akademisyenlerin \%86'sı erkek akademisyenlerden oluşmaktadır (Aiston, 2014). Öte yandan Hada'nın (2013) 18 farklı ülkede yaptığı çalışmasında kadın araştırmacıların en düşük oranla Japonya'da $(\% 11,6)$ olduğu tespit edilmiştir (Morley, 2014: 116).

Türkiye'deki kadın akademisyen oranlarına bakıldığında bu oranın, pek çok Avrupa ülkesindeki kadın akademisyen oranından yüksek olduğu görülmektedir (Şentürk, 2016:2). Türkiye'deki akademisyenlerin yaklaşık \%44'ünü kadınlar oluşturmaktadır (Tablo 1). Fakat veriler incelendiğinde akademik unvan kademeleri yükseldikçe kadın akademisyen oranının azaldığı görülmektedir. Kadın akademisyenlerin sayıca en fazla bulunduğu unvan araştırma görevliliği (\%33) ve öğretim görevliliği (\%25) olurken en az sayıda bulundukları kadrolar ise doçentlik $(\% 7,9)$ ve profesörlük kadrolarıdır (\%10). Farklı pek çok araştırma sonucu da bu bulguları destekler niteliktedir (Okay, 2007; Poyraz ve Ulusoy, 2013: 50; Öztan ve Doğan, 2015; Yılmaz, 2017). Ayrıca 2018 yılı itibariyle 111 devlet üniversitesinin sadece üçünde kadın rektör ve 29 kadın rektör yardımcısı bulunmaktadır (www.haberturk.com, 2018). Sonuç olarak akademik alanda kadın istihdamına diğer alanlara oranla daha çok yer verildiği söylenebilirken karar verici pozisyonlarda kadın akademisyenlerin kendilerine yeterince yer buldukları söylenememektedir.

Tablo 1: Akademisyen Sayıları (2018)

\begin{tabular}{|c|c|c|c|c|c|c|c|c|c|c|c|c|c|}
\hline \multirow{2}{*}{$\begin{array}{c}\text { Üniversite } \\
\text { Türü }\end{array}$} & \multicolumn{2}{|c|}{ Profesör } & \multicolumn{2}{|c|}{ Doçent } & \multicolumn{2}{|c|}{$\begin{array}{c}\text { Dr. Öğretim } \\
\text { Üyesi }\end{array}$} & \multicolumn{2}{|c|}{$\begin{array}{l}\text { Öğretim } \\
\text { Görevlisi }\end{array}$} & \multicolumn{2}{|c|}{$\begin{array}{c}\text { Araştırma } \\
\text { Görevlisi }\end{array}$} & \multicolumn{3}{|c|}{ Genel Toplam } \\
\hline & Erkek & Kadın & Erkek & Kadın & Erkek & Kadın & Erkek & Kadın & Erkek & Kadın & Erkek & Kadın & Toplam \\
\hline Devlet & 14281 & 6557 & 7863 & 4839 & 17907 & 12281 & 15057 & 12979 & 21449 & 21092 & 76557 & 57748 & 134305 \\
\hline Vakıf & 2615 & 1107 & 953 & 755 & 3555 & 3550 & 2470 & 4599 & 1259 & 1996 & 10852 & 12007 & 22859 \\
\hline Vakıf-Myo & 4 & 1 & 3 & 0 & 17 & 14 & 112 & 170 & 0 & 0 & 136 & 185 & 321 \\
\hline Toplam & 16900 & 7665 & 8819 & 5594 & 21479 & 15845 & 17639 & 17748 & 22708 & 23088 & 87545 & 69940 & 157485 \\
\hline
\end{tabular}

\subsection{Kadın Akademisyenler ile İlgili Çalışmalar}

Kadın akademisyenler ile ilgili olarak yapılmış çalışmaların sonuçlarının benzerlik gösterdiği ve çalışmalarda bazı ortak sonuçlara ulaşıldığı görülmektedir. Örneğin, İngiltere'de yapılan bir araştırmanın sonucunda, araştırma kapsamındaki birimlerde cam tavan olgusunun var olduğu, kadın akademisyenlerin görece daha düşük pozisyonlarda bulunduğu ve bu pozisyonlarda erkek meslektaşlarından daha uzun süre görev yaptıkları ortaya çıkmıştır. Aynı zamanda kadın akademisyenler yöneticilik pozisyonlarını, meslektaşlarına oranla kendileri için daha fazla iş yükü olarak değerlendirmektedirler (Doyle ve Hind, 1998). McCall ve diğ.'nin (2000) Avusturalya'da bir tıp fakültesinde yaptıkları çalışmanın sonuçlarına göre, kadın akademisyenlerin yöneticilik pozisyonlarında olmalarını engelleyen en önemli faktörlerden biri "erkekler kulübü" olarak da adlandırılan sosyal ağların (old boys network) dışında kalmaları olarak belirlenmiştir. Hindistan'da yapılmış bir çalışmanın sonuçlarına göre kadın 
akademisyenlerin önünde bulunan engeller; akademik çevre, eşit olmayan ev içi sorumlulukları ve son olarak; sosyal ve akademik ağlardan dışlanma olarak belirlenmiştir (Gupta ve diğ., 2005). Ismail ve Rasdi'nin (2007) Malezya'da 31 kadın profesör ile yaptıkları araştırma sonucunda sosyal ağ kurma ve bu ağlara dahil olmanın, kadın akademisyenlerin kariyer basamaklarını daha hızlı tırmanmalarına yardımcı olduğu sonucuna ulaşılmıştır. Rhoads ve Gu'nun (2012) Çin'de yaptıkları çalışmalarında, kadınların çoklu sorumluluklara sahip olmaları, cam tavan etkisi ve erkeklerin sosyal ağlarına dâhil olamamaları, kadın akademisyenlerin yaşadıkları en büyük sorunlar olarak ortaya çıkmıştır. Vietnam'da yürütülen bir çalışma, kadın akademisyenlerin önünde duran temel engellerin aile yükümlülükleri, yönetici olarak kadınlara yönelik olumsuz cinsiyet kalıpları ve kadın akademisyenlerin yönetim pozisyonlarını alma konusunda isteksizliği olduğunu ortaya koymuştur (Nguyen, 2013). Hong Kong'da yapılmış bir başka çalışmanın sonuçları, yönetim pozisyonlarında az sayıda kadın akademisyen olduğunu, bu akademisyenlerin daha az araştırma desteği aldığını ve daha az yayına sahip olduklarını fakat daha fazla ders yükleri olduğunu ortaya çıkarmıştır (Aiston, 2014). Xu ve diğ.'nin (2017) yine Çin turizm akademisinde yaptıkları çalışmanın sonuçları ise kadın akademisyenlerin erkeklerden sayıca fazla olmasına rağmen yöneticilik pozisyonlarında görece az temsil edildiklerini, ev ve çocuk bakımı gibi işlerin daha çok kadınlar tarafından üstlenildiğini ve erkek akademisyenlerin akademik çalışmaları için daha fazla zaman ayırabildiklerini göstermektedir.

Türkiye'de yapılmış çalışmalarda da paralel sonuçlara ulaşıldığı görülmektedir. Er'in 716 kadın öğretim üyesi ile yaptığı araştırmanın sonuçlarına göre; kadın akademisyenlerin orta ve üst idari pozisyonlarda daha düşük sayıda temsil edildikleri, ev içi sorumlulukları daha çok kendilerinin üstlendiği sonucuna ulaşılmıştır. Ayrıca üniversitelerde kadına karşı tacizin, cinsel ve duygusal nitelikli olarak çok düşük oranda da olsa görüldüğü sonucuna ulaşılmıştır (Er, 2008).

Ergöl ve diğ.'nin (2012) kadın araştırma görevlilerinin iş ve aile yaşamlarını konu edindikleri çalışmalarında ise yine önemli bulgular elde edilmiştir. Geleneksel olarak evde kadına yüklenen rollerin yine kadınlar tarafından yerine getirildiği, evin onarımı, alışveriş, fatura ödeme gibi işleri ise daha çok erkeğin yaptığı belirlenmiştir. Bir diğer çalışmada ise; kadınların eğitim düzeyi, statüsü, geliri, görev süreleri ne olursa olsun, kadının ev içindeki geleneksel rolünü dönüştürmeye yetmediği, ev işleriyle ilgili sorumlulukların büyük oranda kadınlara ait olduğu sonucuna ulaşılmıştır (Dikmen ve Maden, 2012:285).

Portekiz ve Türkiye'deki kadın akademisyenlerin durumunun karşılaştırmalı olarak incelendiği bir çalışmada kadınların ev hanımlığı ve anne rollerinin idari sorumluluk almak istememelerine neden olduğu görülmüştür (Machado Taylor ve Özkanlı, 2013). Kariyerinin başında ya da ortalarında olan kadınlar yükselme konusundaki serzenişlerini dile getirmemekte, çoğu yükselmeyi arzu etmemekte ya da liderlik istediğini açıkça dile getirmemektedir (Morley, 2014). Karakuş (2016) tarafından yapılan bir diğer çalışmada ise, kadın akademisyenlerin bölünme korkusu yaşadıklarından dolayı yöneticiliğe dair mesafeli bir yaklaşım içinde oldukları sonucuna ulaşılmıştır.

Bir başka çalışmada ise kadın akademisyenlerin üniversite yönetimindeki eksik temsilleri üzerinde, "toplumsal cinsiyet ayrımcılığı" algısına rastlanmamış fakat toplumsal cinsiyet temelli belirli zorluklar nedeniyle üst düzey yönetime mesafeli durdukları tespit edilmiştir (Suğur ve Cangöz, 2016: 111). 
Şentürk ve diğ.'nin (2017) devlet ve vakıf üniversitesinde görev yapan akademisyenler üzerinde yaptıkları araştırmada, kadın akademisyenlerin kendilerine yöneltilen geleneksel toplumsal cinsiyet rollerini erkek meslektaşlarına göre daha fazla benimsedikleri tespit edilmiştir. Bu durumun varlığı da yazarlara göre ev içindeki iş bölümündeki adaletsiz dağılım ile somutlaşmakta ve kadın akademisyenlerin "ikinci vardiya" olarak nitelendirebilecek işlere ayırdıkları zaman sonucu akademik performanslarındaki düşüş ile yorumlanmaktadır (Şentürk ve diğ., 2017: 889). Armenti (2004: 213) çocuk sahibi olan kadın akademisyenlerin yayın oranlarının düştüğünü belirtirken; Fox (1991) bu verimsizliğin sebebinin, kadın akademisyenlerin görece daha düşük düzeylerdeki pozisyonlarda bulunmaları, fazla ders yükleri ve daha az araştırma desteği veren kurumlarda çalışıyor olmalarından kaynaklanabileceğine değinmektedir. Bagilhole (1993: 272) ise idari pozisyonlarda çocuğu olan pek çok başarılı erkek akademisyen bulunabilirken, benzer pozisyonlarda evli ve çocuklu bir kadın olarak varlık göstermenin güçlüğüne vurgu yapmıştır.

Öztürk'ün üç üniversitedeki kadın akademisyenler üzerinde yaptığı çalışmasında ise kadınların akademiye giriş aşamasında cam tavan etkisine maruz kalmadıkları fakat unvan kademesi artııça erkek adayların gerisinde kaldıkları görülmüştür (Öztürk, 2017:211).

Kadın akademisyenler üzerinde çalışmalar yapan araştırmacıların ulaştığı en önemli sonuçlardan biri de kadın akademisyenlerin rol çatışmaları yaşamaları ve iş-aile hayatlarını dengeleme konusunda yaşadıkları sıkıntılardır. Rol teorisine göre, hastaneler ve üniversiteler gibi karmaşık örgüt yapılarına sahip kurumlarda çalışanların birden fazla pozisyonda görev alması sık karşılaşılan durumlardan biridir. Rol çatışması; bir bireyden, birbirleriyle uyumlu olmayan veya çatışan iki ya da daha fazla rolü yerine getirmesinin istenmesi sonucunda ortaya çıkan bir durumdur (Sabuncuoğlu, 2008: 35). Kadın akademisyenler çalışan diğer kadınlar gibi aynı zamanda hem anne hem eş hem bir bilim insanı olmanın sorumlukları ve gerektirdiklerini kısıtlı bir zaman diliminde yerine getirmek durumunda ve dolayısıyla rol çatışması yaşamaktadırlar. İş aile çatışması da rol çatışmasının özel bir türü olarak değerlendirilmektedir (Aras ve Karakiraz, 2013:1). Kadın akademisyenler ile ilgili alanyazında rol çatışmasının kadın akademisyenlerin yaşamlarında önemli bir problem olduğu sonucuna ulaşılmıştır (Bagilhole, 1993; Acker ve Armenti 2004; Arthur ve diğ., 2007; Özkanlı, 2007; Neale ve Özkanlı, 2010; Köle, 2011; İrey, 2011; Basurto-Barcia ve Ricaurte-Quijano, 2017).

Özkanlı ve Korkmaz'ın çalışmalarına göre, kadın akademisyenler akademik ilerleme taleplerinin yoğun olduğu yardımcı doçentlik aşamasında, elde ettikleri eş, ev kadını, anne gibi yeni statüler nedeniyle büyük bir rol çatışması yaşamaktadır (Özkanlı ve Korkmaz, 2000: 169). Aile ve annelik sorumluluklarının önceliğine inandıklarından kısmi süreli çalışma, işten ayrılma ya da yönetim pozisyonlarına mesafeli yaklaşım, erkeklere oranla daha çok akademik stres ve aile stresi yaşama, çoğu zaman kendilerinden ödün vererek fedakârlıklarda bulunmaları yine bu alanda elde edilmiş önemli bulgulardır. Güner'in (2008) çalışmasında, kadın akademisyenlerin çocuklarının bakımı, okul arkadaşları ve çocukları ile geçirdikleri sosyal etkinlikler gibi konularda kendilerinden taviz verdikleri görülmektedir.

Portekiz'de yapılan bir çalışmanın sonucunda akademideki kadın ve erkeklerin iş ve aileyi uzlaştırmada önemli zorluklarla karşılaştıkları tespit edilmiştir. Bu zorluklar özellikle bebek veya küçük yaşta çocuğu olan kadın akademisyenler tarafından daha fazla hissedilmektedir. Bu sonuç, ailedeki geleneksel cinsiyet rollerinin etkili olmasına ve etkin bir mevzuatın olmamasına bağlanmaktadır (Gaio Santos ve Cabral-Cardoso, 2008: 453). 
Doktora yapan araştırma görevlileri üzerine yapılmış bir çalışmanın sonuçları iş, aile çatışması- iş tatmini ve iş, aile çatışması- başarı hissi arasında negatif ilişki olduğunu göstermiştir (Aras ve Karakiraz, 2013).

Kenya'da yapılmış bir çalışmanın bulguları, araştırma kapsamında görüşülen on altı kadın akademisyenin, çatışmalar ve gerginliklerle sonuçlanan aile sorumluluklarını ve kariyer beklentilerini bir potada eritmenin zorluğunu ortaya koymaktadır. Görüşülen akademisyenlerden bazıları kariyeri için evliliği ertelerken bazıları da ailevi sorumluluklar nedeniyle kariyerlerinden feragat etmişlerdir (Raburu, 2015).

Küçükşen ve Kaya'nın (2016) yöneticilik görevi bulunan 10 kadın akademisyen ile gerçekleştirdiği çalışmasına göre, yönetici akademisyenlerin, iş, aile özel alan dengesini kurabilmek için, özveri, disiplin, fedakârlık gibi özellikleri sayesinde, hedef odaklı çalışmaları ve zaman yönetimindeki becerileri ile aile-iş dengesini kurdukları ancak kendi kişisel, özel intiyaçlarından ödün verdikleri görülmektedir. Ayrıca yönetici pozisyonda aile iş özel yaşam dengesinin kurulabilmesi için, eş desteğinin önemli olduğu tespit edilmiştir.

Özellikle okul öncesi çağında çocuğu olan akademisyen annelerin karşılaştıkları zorluklar üzerinde yapılmış bir çalışmanın sonuçları araştırmaya katılan akademisyenlerin anne olma deneyimlerine değer verdiklerini fakat fazla iş yükü altında ezildiklerini; idari destekten uzak olduklarını ve akademik görevleri ile ebeveyn sorumlulukları arasında denge kurmak için bitmeyen bir mücadele verdiklerini göstermiştir (Günçavdı ve diğ., 2017).

Kadın akademisyenlerin sahip oldukları çoklu rollerin, iş ve aile yaşamlarını dengeleme noktasında zorluklar oluşturduğu görülmektedir. (Forster, 2000; Probert, 2005; O'Laughlin ve Bischoff, 2005; Comer ve Stites-Doe, 2006; Özkanlı, 2007; Monroe vd, 2008; Schneidervd, 2011; İrey,2011; Small ve diğ., 2011, Ergöl ve diğ., 2012; Toffoletti ve Starr, 2016; Basurto-Barcia ve Ricaurte-Quijano, 2017). Caplan'ın (1993: 185) çalışmasında kadın akademisyenlerin aile ile ilgili sorumluluklarından dolayı akademiyi bırakma noktasına gelebildikleri, kalanların da neredeyse yarısının bekâr ya da çocuksuz oldukları ortaya konmuştur.

Bir başka araştırmada ev ve iş yaşamı çatışmasının, kadın profesörlerin kariyer gelişimleri üzerinde olumsuz etkileri olduğu vurgulanmıştır (Healy ve diğ.,2005). O'Laughlin ve Bischoff' un (2005) çalışmaları da erkeklere kıyasla kadınların daha çok akademik stres ve aile stresi yaşadıklarını; iş ve aile dengesi konusunda daha az kurumsal destek algısına sahip olduklarını göstermiştir. Dört kadın akademisyen üzerinde iş aile dengesi konusunda ele alınmış bir başka çalışmanın sonucunda da bu uyumsuzluğun kadın akademisyenlerin hayatına stres, uykusuzluk, fiziksel ve zihinsel sağlık problemleri olarak yansıdığı görülmüştür (Small ve diğ., 2011).

\section{Yöntem}

Çalışmanın araştırma grubunu Türkiye genelinde turizm eğitimi veren devlet üniversitelerinde görev yapan kadın akademisyenler oluşturmaktadır. Çalışma kapsamına giren kadın akademisyenlerin mail adreslerine internet üzerinden oluşturulan online bir araştırma formu yollanmıştır. Bu formda kendilerinden kadın akademisyeni herhangi bir şeye benzetmeleri ve neden bu benzetmeyi yaptıklarını açıklamaları istenmiştir. Formun ilk bölümünde her bir katılımcıdan, "kadın akademisyen...dır/gibidir; çünkü..." cümlesini tamamlamaları istenmiştir. İkinci bölümde ise katılımcıların demografik özelliklerini belirlemeyi amaçlayan 6 soru bulunmaktadır. 
Veri toplama süreci sonunda 141 kadın akademisyenden geri dönüş alınmış ve 137 adet geçerli metafor üretilmiştir. Nitel araştırma deseninin kullanıldığı çalışmada veriler içerik analizi tekniği kullanılarak çözümlenmiş ve katılımcıların hangi temalardan metaforları daha çok kullandıkları belirlenmiştir. İçerik analizinde amaç, birbirine benzeyen verileri belirli kavramlar ve temalar çerçevesinde bir araya getirmek ve bunları okuyucunun anlayabileceği bir biçimde düzenleyerek yorumlamaktır. (Yıldırım ve Şimşek, 2008:227). Kadın akademisyenlerin kadın akademisyen olma kavramını zihinlerinde hangi imgelerle içselleştirdiklerini araştıran bu çalışmanın araştırma soruları şunlardır: "Kadın akademisyenlerin, "kadın akademisyen" kavramına ilişkin sahip oldukları metaforlar ve nedenleri nelerdir?" ve "Kadın akademisyenlerin, "kadın akademisyen" kavramına yönelik metaforları kaç farklı kategoride toplanabilir?" Araştırmaya katılan kadın akademisyenlerin ürettiği geçerli metaforlar dört aşamada analiz edilmiştir. Bu aşamalara aşağıda sırası ile değinilmektedir.

- Verilerin Ayıklanması Aşaması: Bu aşamada elde edilen veriler Excel tablosuna alınmış, her metafor kodlanmış, boş bırakılmış formlar elenmiştir. Ayrıca bazı katılımcılar ürettikleri metaforların nedenini veya gerekçesini sunmamıştır. Bu şekildeki 4 adet veri formu araştırma kapsamı dışında bırakılarak 137 adet geçerli metafor üzerinden veri analizi gerçekleştirilmiştir.

- Oluşturulan metaforların araştırmacılar tarafından ayrı ayrı kodlanarak metafor tablosunun oluşturulması: Araştırmacıların her biri tarafından katılımcıların ürettiği geçerli metaforlar belirlemiş ve bir metafor tablosu oluşturulmuştur. Araştırmacılar tarafından uzlaşılan metaforlar alfabetik sıraya konularak tasnif edilmiştir.

- Kodlamaların karşılaştırılması ve ortak temalara ulaşılması: Çalışmanın bu aşamasında metaforlar sahip oldukları ortak özellikler bakımından incelenmiştir. Araştırmacılar tarafından hangi metaforun hangi ortak temalar altında kalabileceği belirlenmiştir. Bu işlem sonrasında 13 adet tema belirlenmiştir. Üretilmiş bazı metaforlara farklı anlamlar yüklendiğinden söz konusu metaforlar farklı temalar altında işlenmiştir (örneğin "kırmızı", "ağaç"). Bulgular bölümünde doğrudan alıntılar yoluyla metaforlar ve tema ilişkisine yer verilmiştir.

- Geçerlik ve güvenirlik çalışması: Çalışmanın iç güvenirliğinin artırmak noktasında bulguların tamamı yorum yapılmadan doğrudan verilmiştir. Ayrıca elde edilen veriler üzerinde araştırmacılar iki ayrı akademisyenden ayrı ayrı kodlamalar yapmasını istemiş ve kodlamalar karşılaştıılarak tutarılıık oranı hesaplanmıştır. Bu hesaplama sonrası Kappa değeri 0,75 olarak bulunmuştur. Bu değerin 0,61 ile 0,80 arasında olması, önemli düzeyde bir uyumun olduğu şeklinde yorumlanmaktadır (Landis ve Koch, 1977). Araştırmanın geçerliği için ise araştırma süreci, bu süreçte yapılanlar ve veri analiz süreçleri ayrıntılı olarak açıklanmıştır. Katıımcıların ürettiği metaforlardan doğrudan alıntılara yer verilerek raporlaştırılmıştır.

\section{Bulgular}

Tablo 2 incelendiğinde çalışmaya katılan kadın akademisyenlerin büyük çoğunluğunun doktor öğretim üyesi ve araştırma görevlisi olduğu görülmektedir. Çalışmaya katılanların \%41'ının idari görevi olduğu, \%67'sinin evli olduğu görülmektedir. Akademisyenler çocuk sahibi olma bakımından incelendiğinde büyük çoğunluğunun (\%60) bir çocuğu, \%36'sının iki çocuğu ve yalnızca \%3'ünün üç çocuğu olduğu görülmektedir. 
Tablo 2:. Katılımcıların Demografik Özellikleri

\begin{tabular}{llll}
\hline Kriterler & & $\mathbf{f}$ & $\%$ \\
\hline Unvan & Profesör & 9 & 6,5 \\
& Doçent & 18 & 13,1 \\
& Dr. Öğr. üyesi & 43 & 31,3 \\
& Dr. & 7 & 5,1 \\
& Öğretim görevlisi & 18 & 13,1 \\
& Araştırma görevlisi & 42 & 30,6 \\
\hline Çalışma süresi & 1 yıldan az & 2 & 1,5 \\
& $1-5$ yıl & 41 & 29,9 \\
& $6-10$ yıl & 38 & 27,7 \\
& $11-15$ yıl & 22 & 16,1 \\
& $16-20$ yıl & 16 & 11,7 \\
& 21 yıl ve üzeri & 18 & 13,1 \\
\hline İdari görev & Var & 56 & 40,9 \\
& Yok & 81 & 59,1 \\
\hline Medeni durum & Evli & 92 & 67,2 \\
& Bekar & 45 & 32,8 \\
\hline Çocuk & Var & 86 & 62,8 \\
& Yok & 51 & 37,2 \\
\hline Çocuk sayısı & 1 & 52 & 60,4 \\
& 2 & 31 & 36,2 \\
& 3 & 3 & 3,4 \\
\hline Toplam & & 137 & 100 \\
\hline
\end{tabular}

Çalışma kapsamında 137 adet geçerli metafor üretilmiş ve bu metaforlar 13 tema altında gruplandırılmıştır. Elde edilmiş 13 tema ve temalara ilişkin frekans dağılımları Tablo 3'de görülmektedir. Tabloda görüldüğü üzere temalar sırası ile, "mücadele etmesi gereken biri olarak", "çoklu görevlere sahip biri olarak", "çalışkan biri olarak", "zarif biri olarak", "engellenen biri olarak", "üretken biri olarak", "mucizevi bir varlık olarak", "enerjik ve canlı biri olarak", "güçlü biri olarak", "fedakâr biri olarak", "yol gösterici biri olarak", "uyum sağlaması gereken biri" ve "denge sağlaması gereken biri olarak kadın akademisyen" temalarıdır. Aşağıda bu temaların ihtiva ettiği metaforlar ayrı ayrı incelenerek sunulmaktadır.

Tablo 3: Elde Edilen Temalar

\begin{tabular}{ll} 
Temalar & Metaforlar \\
\hline $\begin{array}{l}\text { Mücadele etmesi gereken biri } \\
\text { olarak kadın akademisyen }\end{array}$ & Yarış Atı (5), Amazon Kadını (5), Zeyna \\
temasında üretilen metaforlar & At, Düdüklü Tencere Kaplumbağa, \\
& Kayık, Kırmızı Başlıklı Kı, Kırmızı, \\
& Panter, Renk, Gri, Su Ayısı, Bir Şekil, \\
& Adile Naşit, Çınar Ağacı, Donkişot, Kedi, \\
& Dişi Aslan
\end{tabular}


Çoklu Görevlere Sahip Biri Ahtapot (10), Gök Kuşağı (3), Ağaç (3), Olarak Kadın Akademisyen

Bulut, Renkli Bir Spiral, Akrobat, Köle, Zaman, Tiyatro Sanatçısı, Hızlı Gonzales, Hindu Tanrıçası "Durga”, Çok Yönlü Bir Zar, Kanguru, Kaplan, Külkedisi, Mor, Artist, Renkleri Birbirine Geçmiş Bir Suluboya Tablo, Pervane, Emek

\begin{tabular}{|c|c|c|}
\hline $\begin{array}{l}\text { Çalışkan Biri Olarak Kadın } \\
\text { Akademisyen }\end{array}$ & Karınca (8), Arı (2), At, Mavi & 12 \\
\hline $\begin{array}{l}\text { Zarif Biri Olarak Kadın } \\
\text { Akademisyen }\end{array}$ & $\begin{array}{l}\text { Ceylan (4), Kuğu (2), Çiçek, Kırmızı, } \\
\text { Cam, At, Beyaz }\end{array}$ & 11 \\
\hline $\begin{array}{l}\text { Engellenen biri } \text { olarak kadın } \\
\text { akademisyen } \\
\text { üretilen metaforlar }\end{array}$ & $\begin{array}{l}\text { Yedek Oyuncu (2), Kırmızı (2), Kafesteki } \\
\text { Kuş, Kurtlar Sofrası, Ters Dönmüş } \\
\text { Kaplumbağa, Üçgen, Ağaç }\end{array}$ & 9 \\
\hline $\begin{array}{l}\text { Üretken Biri } \text { Olarak Kadın } \\
\text { Akademisyen }\end{array}$ & $\begin{array}{l}\text { Yeşil (2), Artemis Heykeli, Bereket } \\
\text { Tanrıçası "Kibele", Toprak Ana, Fatma } \\
\text { El-Fihri, Tarihsel Kimlik }\end{array}$ & 7 \\
\hline $\begin{array}{l}\text { Mucizevi Bir Varlık Olarak } \\
\text { Kadın Akademisyen }\end{array}$ & $\begin{array}{l}\text { Polyanna, Superman, Tinker Bell, } \\
\text { Wonder woman, Deniz Kızı, Külkedisi }\end{array}$ & 6 \\
\hline $\begin{array}{l}\text { Enerjik ve Canlı Biri Olarak } \\
\text { Kadın Akademisyen }\end{array}$ & $\begin{array}{l}\text { Kırmızı (3), Günebakan, Kırmızı Çiçek, } \\
\text { Renk }\end{array}$ & 6 \\
\hline $\begin{array}{l}\text { Güçlü Biri Olarak Kadın } \\
\text { Akademisyen }\end{array}$ & Arslan (2), Fil, Kırmızı, Mor & 5 \\
\hline $\begin{array}{l}\text { Fedakâr Biri Olarak Kadın } \\
\text { Akademisyen }\end{array}$ & Anne (2), At (2) & 4 \\
\hline $\begin{array}{l}\text { Yol Gösterici Biri Olarak } \\
\text { Kadın Akademisyen }\end{array}$ & Baykuş (2), Ay Tanrıçası "Hekate", Mavi & 4 \\
\hline $\begin{array}{l}\text { Uyum Sağlaması Gereken Biri } \\
\text { Olarak Kadın Akademisyen }\end{array}$ & Oyun Hamuru, Su, Bukalemun & 3 \\
\hline $\begin{array}{l}\text { Denge Sağlaması Gereken Biri } \\
\text { Olarak Kadın Akademisyen }\end{array}$ & Bisiklet, Beauty and the Beast: Belle & 2 \\
\hline
\end{tabular}

Tema 1: Mücadele Etmesi Gereken Biri Olarak Kadın Akademisyen

$\mathrm{Bu}$ tema toplam 35 metafor ile en çok metafor geliştirilen tema olmuştur. Katılımcılar en sık olarak "yarış atı", "amazon kadını", "Zeyna" ve "masal kahramanı" metaforlarını kullanmışlardır. Aşağıda bu temada üretilen metaforlardan katılımcıların doğrudan ifadelerine dayanan örnekler sunulmuştur.

- Amazon kadını - "Sürekli mücadele etmeyi, bir şeyler ile savaşmayı gerektirdiği için" (Katılımcı (K), 21)

- Zeyna - "Devamlı mücadele etmesi gerektiği için (erkeklere oranla daha fazla)" (K, 134)

- Kırmızı - "Akademik ortamda kadın olmak zordur. En basit anlamda örneğin pasif bir kişiliğiniz var ise güçlüklerle baş edemez olarak değerlendirilebilir ve zayıf görülebilirsiniz. Güçlü bir kişiliğiniz var ise bu kez de yönetilmesi zor olarak değerlendirebilirsiniz. Her iki durum da kadın akademisyenin aşması gereken güçlükler söz konusu bu nedenle kırmızı ile temsil edilebilir. "(K, 93)

- Yarış atı- "Kadınlar güçlü olduklarını gösterebilmek için engelleri kendi çabalarıyla aşmaya çalışıyorlar ve orada kendilerinin de olduklarını herkese 
kanıtlıyorlar, toplumumuz ya da iş çevremiz başarılı kadınları karşılarında görmek istemiyorlar. Önceliğin, söz hakkının her zaman kendilerinde olmasını istiyorlar." $(K, 107)$

\section{Tema 2: Çoklu Görevlere Sahip Biri Olarak Kadın Akademisyen}

Temanın toplam 33 metafor ile en çok metafor geliştirilen ikinci tema olduğu görülmektedir. Katılımcılar bu temada en çok "ahtapot", "gökkuşağı" ve "ağaç" kavramlarını kullanmışlardır. Bu temada yer alan metaforları üreten katıımcıların doğrudan ifadelerine aşağıda yer verilmiştir.

- Ağaç - "Çünkü kadın olmanın yükü çok fazla. Çok fazla toplumsal role ve sorumluluğa sahip. Bu sebeple bir ağaç gibi kökleri sağlam, sayısız fayda sağlayan ve dallarında taşıdığı yüzlerce yaprakları (sorumlulukları) olan bu canlıya benzettim." ( $K, 5)$

- $\quad$ Ahtapot - "Çünkü başarmak zorunda olduğu birçok şey var. lyi bir eğitimci, iyi bir araştırmacı, bakımlı bir kadın, iyi bir anne, iyi bir eş, iyi bir gelin, aşşı, temizlikçi vb. olması için ikiden fazla kolu olması gerekir." (K, 73)

- Kanguru- "Kesene her şeyden bir miktar koyuyorsun annelik, danışmanlık, eğitimci, eş, kariyer, mücadele, yol gösteren bu arada kendi yolunu da yaşayarak bulan..." $(K, 75)$

\section{Tema 3: Çalışkan Biri Olarak Kadın Akademisyen}

Bu temada toplam 12 metaforun üretildiği görülmektedir. En fazla tekrar edilen metaforların "karınca" ve "arı" olduğu görülmektedir. Diğer üretilen metaforlar ise "at" ve "mavi" metaforlarıdır. Aşağıda katılımcı ifadelerinden bazılarına yer verilmektedir.

- Karınca-"Karıncalar çalışkan ve daima insanlara örnek gösterilen hayvancıklardır." $(K, 82)$

- Arı- "Çünkü her an, her yerde çalışıyorlar." (K, 24)

- At- "Sürekli koşmak zorunda olduğu için" $(K, 34)$

\section{Tema 4: Zarif Biri Olarak Kadın Akademisyen}

$\mathrm{Bu}$ temada en sık tekrar eden metaforların "ceylan" ve "kuğu" olduğu görülmektedir. Bu temada 11 metafor oluşturulmuştur. Bazı katılımcı ifadelerine aşağıda yer verilmektedir.

- Çiçek - "Merak uyandırıcı, yararlı, zarif olduğu için " $(K, 71)$

- Ceylan - "Hem çok güzel hem çok kırılgan, narin olduğu için" $(K, 51)$

- Kuğu- "Diğer meslekler içinde son derece zarif, farklı ve kendinden emin bir duruş içermesi" (K, 97)

\section{Tema 5: Engellenen Biri Olarak Kadın Akademisyen}

Bu temada toplam 9 adet metafor üretilmiş olup, en sık üretilmiş metaforlar "yedek oyuncu" ve "kırmızı" kavramları olmuştur. Bu temada yer alan katılımcı ifadelerinden bazılarına aşağıda yer verilmektedir.

- Kafesteki kuş - "Aslında özgür olması gerekirken bir kafese yani akademik koşturmacanın içerisine sıkışmış ve bütün dünya nimetlerinden yoksun kalmıştır. Hayatı kaçırmıştır" $(K, 74)$ 
- Ağaç- "Kökleri sağlam olmalı çünkü üstten budamak isteyen çok var.” $(K, 7)$

- Yedek oyuncu - "Yapacaklarını ortaya koymalarına fırsat verilmez. Onlar için kadın "acaba"yı, "olumsuz ihtimali" ifade eder. Maalesef bizim ülkemizde kadın akademisyene doçent olana kadar akademisyen gözüyle dahi bakılmaz. Ne kadar önemli iş yaparsa yapsın, sözleri ciddiye alınmaz ne zamanki asıl oyuncu olur, gol atar, rütbe alır o zaman dikkate alınır." $(K, 62)$

\section{Tema 6: Üretken Biri Olarak Kadın Akademisyen}

Bu temada toplam 7 metaforun üretildiği görülmektedir. En fazla tekrar edilen metaforun "yeşil" olduğu görülmektedir. Diğer üretilen metaforlar ise "Artemis heykeli" ve "Kibele", "toprak ana", "Fatma el-fihri" ve "tarihsel kimlik" metaforlarıdır. Aşağıda katılımcı ifadelerinden bazılarına yer verilmektedir.

- Bereket tanrıçası Kibele-“Üretken verici sevecen”(K,38)

- Yeşil- "Çünkü yeşil renk verimliliği temsil eder" $(K, 130)$

- Toprak ana- "Çünkü sahiplenici ve verici, bereketli, verimli, affedici" $(K, 123)$

- Artemis heykeli-"Bolluk ve bereket tanrıçası Artemis hem zarafetiyle hem de tanrıça misyonuyla antik dönemin önemli bir figürüdür. Akademik anlamda iyi bir bilgi ve donanıma sahip kadınlar bunu yetiştirdiği öğrencilerine de yansıtır" $(K, 27)$

- Fatma EI Fihri-“Dünyanın ilk üniversitesini kurmuş olmasından...” $(K, 121)$

\section{Tema 7: Mucizevi Bir Varlık Olarak Kadın Akademisyen}

Bu temada toplam 6 adet metafor üretilmiş olup, bunlar metaforlar "Polyanna", "Superman", "Tinkerbell", "Wonderwomen", "Deniz kızı", ve "Külkedisi” olmuştur. Bu temada yer alan katılımcı ifadelerinden bazılarına aşağıda yer verilmektedir.

- Superman- "Her işe koşan" (K, 119)

- Wonderwoman- "Özel hayatına, evine, işine, varsa eğer çocuklarına dengeli bir şekilde zaman ayırmak, aynı zamanda bunları yaparken okulda da bir bilim insanı olmanın gerekliliklerini layıkıyla yerine getirmeye çalışmak tam bir süper kahraman olmayı gerektiriyor. Gerektiğinde uçacaksın, yorgunluk diye bir hissi bilmeyeceksin, bir yerden bir yere klonlanacaksın, sonunda o işi yapacaksın." (K, 136)

- Külkedisi-“çünkü kadın akademisyen olmak zor ama bir o kadar güzeldir. Külkedisi gibi en ağır yükleri omuzlayarak sürekli çalışmak durumundasınız ama yeri geldiğinde de (bir akademik çalışma veya dersteki performansınızla) bir prensese dönüşerek gecenin ve masalın yıldızı olursunuz." $(K, 77)$

\section{Tema 8: Enerjik ve Canlı Biri Olarak Kadın Akademisyen}

Bu temada toplam 6metaforun üretildiği görülmektedir. En fazla tekrar edilen metaforun "kırmızı" olduğu görülmektedir. Diğer üretilen metaforlar ise "günebakan", "kırmızı çiçek" ve "renk" metaforlarıdır. Aşağıda katılımcı ifadelerinden bazılarına yer verilmektedir.

- Kırmızı- "Her zaman neşeli, enerjik ve otokontrol gerektirdiği için." (K, 89)

- Günebakan - "Çiçek olarak hep dik duran ve güneşe dönük olduğu için. Enerjik ve güler yüzlü biriyim.” ( $K, 66)$ 
- Renk- "Kadınlar bulunduğu ortama düzen, enerji, farklılık ve heyecan getirir." $(K, 15)$

\section{Tema 9: Güçlü Biri Olarak Kadın Akademisyen}

Bu temada toplam 5 adet metafor üretilmiş olup, bu metaforlar "arslan", "fil", "kırmızı", "mor" olmuştur. Bu temada yer alan katılımcı ifadelerinden bazılarına aşağıda yer verilmektedir

- Arslan- "Akademik hayatın en gösterişli, en hayranlık duyulan, en güçlü üyesi” $(K, 26)$

- Kırmızı- "Kırmızı rengi güç olarak algılıyorum, iddialı bir renk ve kadın akademisyenlerde bu mesleği yaparak güçlü olduklarını gösteriyor.” (K, 113)

- Mor - "Renklerin anlamlarından yola çıkarak, mor rengin yaratıcılığı, gücü ve gerektiğinde otoriter bir bilim insanı ve eğitimci olma özelliğini simgelediğini düşünüyorum." $(K, 102)$

\section{Tema 10: Fedakâr Biri Olarak Kadın Akademisyen}

Bu temada toplam 4 metaforun üretildiği görülmektedir. En fazla tekrar edilen metaforların "anne" ve "at" olduğu görülmektedir. Aşağıda katılımcı ifadelerinden de görülebileceği gibi kadın akademisyenlerin kimi zaman kendi kişisel yaşamlarından ödün verdikleri anlaşılmaktadır.

- At- "At sadık ve fedakâr bir hayvan. Kocası önce yükselsin diye, çocuğuna daha fazla vakit ayırmak için, toplumsal cinsiyet kendisine bir adım geride durmayı öğrettiği için hep kendisinden fedakârlık yapıyor." $(K, 30)$

- Anne- "Özveri ve fedakâr, çalışkan olduğu için" (K, 33)

\section{Tema 11: Yol Gösterici Biri Olarak Kadın Akademisyen}

$\mathrm{Bu}$ temada toplam 4 adet metafor üretilmiş olup, bu metaforlar "baykuş", "Hekate" ve "mavi" olmuştur. Bu temada yer alan katılımcı ifadelerinden bazılarına aşağıda yer verilmektedir.

- Baykuş- "Bilgelik sadece kadına ve baykuşa özgüdür." (K, 35)

- Hekate - "Ay tanrıçası olarak karanlık gecelerde yolculara yol gösterir." (K, 67)

- Mavi - “... güvenilir olması gerektiği için.” $(K, 1)$

\section{Tema 12: Uyum Sağlaması Gereken Biri Olarak Kadın Akademisyen}

Bu temada toplam 3 metaforun üretildiği görülmektedir. Bu metaforların "oyun hamuru", "su" ve "bukalemun" olduğu görülmektedir. Aşağıda katılımcı ifadelerine de yer verilmektedir.

- Bukalemun-"Her türlü ortama uyum sağlayıp onlardan biriymiş gibi görünmek zorunda özellikle eril egemen bir toplumda onlardan biriymiş gibi davranıp kendini kabul ettirmek çok zor bir iştir. Bunu becerebilen tek hayvan olan bukalemun gibi kadınların da erkek hegemonyasında olan dünya düzeninde kendine yer edinmek için onlardan biriymiş gibi görünmeleri gerektiğini düşünüyorum" (K, 46) 
- Oyun hamuru- "Çalıştıkları kurumdaki ve dışardaki insanlar tarafından sürekli bir şekle sokulma çabasıyla karşı karşıya kaldıkları için kadın akademisyenleri oyun hamuru olarak nitelendiriyorum" $(K, 105)$

- Su - "Her kabın şeklini alıyor, almak zorunda." $(K, 117)$

\section{Tema 13: Denge Sağlaması Gereken Biri Olarak Kadın Akademisyen}

Bu temada toplam 2 adet metafor üretilmiş olup, bu metaforlar "bisiklet" ve "Belle" olmuştur. Bu temada yer alan katılımcı ifadelerini aşağıda yer verilmektedir.

- Bisiklet- "Akademisyenlik sizin yapınıza uygunsa ve akademisyen olmayı tercih ettiyseniz, hayat içerisindeki dengelerinizi bozmadan ilerleyebilmeli ve tadını çıkarabilmelisiniz." (K, 45)

- Beauty and the Beast: Belle- "Devamlı okumak gerekiyor, güzel ile çirkini ayırt etmeyeceksiniz, her öğrenciye eşit şartları tanımanız gerekiyor." $(K, 51)$

\section{Sonuç ve Öneriler}

$\mathrm{Bu}$ çalışmada Türkiye genelinde turizm alanında çalışan kadın akademisyenlerin "kadın akademisyen olma" algısını zihinlerinde nasıl betimledikleri metaforlar yolu ile araştırılmış olup araştırma kapsamında 137 adet geçerli metafor üretilmiş ve bu metaforlar 13 tema altında gruplandırılmıştır. Bu temalar sırası ile "mücadele etmesi gereken biri olarak kadın akademisyen", "çoklu görevlere sahip biri olarak kadın akademisyen", "çalışkan biri olarak kadın akademisyen", "zarif biri olarak kadın akademisyen", "engellenen biri olarak kadın akademisyen", "üretken biri olarak kadın akademisyen", "mucizevi bir varlık olarak kadın akademisyen", "enerjik ve canlı biri olarak kadın akademisyen", "güçlü biri olarak kadın akademisyen", "fedakâr biri olarak kadın akademisyen", "yol gösterici biri olarak kadın akademisyen", "uyum sağlaması gereken biri olarak kadın akademisyen" ve "denge sağlaması gereken biri olarak kadın akademisyen" olarak isimlendirilmiştir.

Üretilen metaforlar incelendiğinde en çok metafor üretilmiş temanın "mücadele etmesi gereken biri olarak kadın akademisyen" olduğu dikkat çekmektedir. Kadın akademisyenler bu temada kendilerini bir savaşçıya ya da hayatta kalma mücadelesi veren çeşitli canlılara benzetmişlerdir. Çalışmadan çıkan sonuçlara göre ev içindeki sorumluluklar daha önce yapılmış çalışmalarda da görüldüğü gibi eşit bir şekilde paylaşılamamakta; toplumsal cinsiyet rolleri gereği ev işleri ve çocuk bakımı gibi işler kadına atfedilmektedir (Santos ve Cabral-Cardoso, 2008; Er, 2008; Ergöl ve diğ., 2012; Dikmen ve Maden, 2012; Nguyen, 2013; Şentürk ve diğ., 2017; Xu, 2017). Zorlu tempolarında hem anne hem eş hem de bir bilim insanı olmanın gerekliliklerini yerine getirmenin, kadın akademisyenleri mücadele etmek durumunda bıraktığı görülmektedir. Ayrıca iş yerinde maruz kaldıkları bazı ayrımcı ve önyargılı uygulamalar da kadınların birkaç cephede mücadele etmesine sebep olmaktadır. Monroe ve diğ. (2008); Small ve diğ., (2011); Munar ve diğ.'nin (2015) çalışmaları bu olguyu desteklemekte olup, üniversitelerdeki geleneksel cinsiyet rollerini gözler önüne sermektedir.

Bu tema ile bağlantılı olarak ikinci tema da "çoklu görevlere sahip biri olarak kadın akademisyen" olarak belirlenmiştir. Pek çok çalışmada zaten kadın akademisyenlerin çoklu görevlere sahip olmasının hem kişisel hem de akademik hayatlarını olumsuz yönde etkilediği ve kadın akademisyenlerin rol çatışması yaşadıkları sonucuna ulaşılmıştır (Bagilhole, 1993; Acker ve Armenti, 2004; Arthur ve diğ.,2007; Neale ve Özkanlı, 2010; İrey, 2011; Köle, 2011; Toffoletti ve Starr, 2016; 
Basurto-Barcia ve Ricaurte-Quijano, 2017). Özkanlı'nın çalışmasında kadın akademisyenlerin çoklu rolleri dolayısıyla idari pozisyonlarda yer almayı istemedikleri sonucu ortaya konmuştur (Özkanlı, 2007: 67). Türkiye ve Avustralya üniversitelerinde kadın liderliği konusunda yapılan çalışmanın sonucuna göre, kadın akademisyenlerin yönetim pozisyonlarında eksik temsillerinin büyük oranda rol çatışmasına bağlı olduğu sonucuna ulaşılmıştır (Özkanlı ve White, 2009). Acker ve Armenti (2004) kadın akademisyenlerin çocukla birlikte akademik kariyer yapmalarını stres, uykusuzluk ve tükenmişlikle ilişkilendirmiştir. Belkıs'ın yaptığı çalışmaya göre anneliğin özellikle doğumdan sonraki ilk üç yıl için kadın akademisyenlerin yaşamına ve akademik faaliyetlerine dikkat dağınıklığı, odaklanamama, yorgunluk, uykusuzluk, kaygı gibi etkilerle yansıdığı görülmektedir (Belkıs, 2016:250). Kaldı ki Caplan (1993) ve Poyraz'ın çalışmalarında (2013: 16) kadın akademisyenler içerisinde kendisini mesleğine adayanların daha çok bekâr ya da çocuksuz oldukları görülmektedir. Çalışmamızda da kadın akademisyenlerin yarıdan fazlasının (\%60) tek çocuğa sahip olması da bu bulguları destekler niteliktedir. Özkaplan'ın (2013: 20) çalışmasında da bekar kadınlar, akademik kariyer merdivenlerinde, evli kadınlara göre, bekar kadın olmanın avantajlarından söz etmiş ve kadın profesörlerin medeni durumları incelendiğinde \%90'ının bekar, boşanmış da dul oldukları ortaya çıkmıştır.

Araştırmada elde edilen temalardan bir diğeri de yine ilk iki temayı destekleyecek nitelikte "fedakâr biri olarak kadın akademisyen" olarak yansımıştır. Toplumsal cinsiyet rollerini omuzlarında hisseden kadın akademisyenlerin mücadele ettikleri tüm cephelerde başarılı olmak için bazen kendi sosyal yaşamlarından bazen de aile hayatlarından kimi zaman da akademik kariyerlerinden ödün vermek durumunda kaldıkları anlaşılmaktadır. Alanyazındaki diğer çalışmaların sonuçlarına göre kadın akademisyenlerin çoğu zaman çocuklarına gereken özeni gösteremediklerini düşünmeleri suçluluk duymalarına da neden olabilmektedir (İrey, 2011; Köle 2011; Başarır ve Sarı, 2015). Kısıtlı zamanları dolayısıyla kadın akademisyenlerin meslektaşlarıyla ve dostlarıyla olan sosyal ilişkileri de olumsuz etkilenebilmektedir (Wall, 2008: 226). Küçükşen ve Kaya'nın (2016) çalışma sonuçları da destekler nitelikte olup, kadın akademisyenlerin özveri, fedakârlık gibi özellikleri sayesinde, aile ve iş dengesini kurdukları ancak kendi kişisel, özel intiyaçlarından ödün verdikleri görülmektedir.

Çalışmada metaforlardan ulaşılan bir diğer tema da "çalışkan biri olarak kadın akademisyen" temasıdır. Kadın akademisyenlerin çoğunluğunun akademik çalışmalarını eve taşıdığı, mesai saatleri dışında da çalışmalarını evde sürdürdüğü ve hatta özel yaşamlarından fedakârlık yaptıkları görülmektedir (Özkanlı ve Korkmaz, 2000). Özkaplan'ın çalışmasında (2013: 20) evli ve evli-çocuklu kadınlar, "yeterli" sayılabilmek için, akademik çalışmalara erkek meslektaşlarından daha fazla asılmaları gerektiğini vurgulamışlardır. Sabatier'in (2006) Fransa'da yaptığı çalışması bu bulguyu desteklemektedir. Kadın ve erkek akademisyenlerin özgeçmişleri analiz edilmiş, erkek ve kadın akademisyenlerin farklı terfi kriterleri olduğu ortaya çıkmıştır. Çalışmaya göre kadın akademisyenler terfi etmek için, bilimsel etkinliklerin farklı boyutlarında erkeklere göre daha fazla katılım göstermelidirler (Sabatier, 2006). Bu da beraberinde daha fazla çalışmayı gerektirmektedir. Bu sonuç eşitlik kuramına ters düşmekte, erkek ve kadın akademisyenler aynı oranda katkılar sunsa dahi kadın akademisyenlerin söz konusu görece yüksek pozisyonlara gelmesi daha zor olmakta bu da kadın akademisyenin akademik hayatında gerilimlere neden olabilmektedir.

Kadın akademisyenlerin çoklu rollere sahip olması aynı zamanda iş ve aile yaşamlarını dengeleme noktasında da bazı problemler yaşadıklarını ortaya koymaktadır. Buna paralel olarak çalışmada elde edilmiş temalardan bir diğeri de 
"denge sağlaması gereken biri olarak kadın akademisyen" olarak çıkmıştır. Ergöl ve diğ.'nin (2012), çalışma bulgularına göre her iki kadın akademisyenden birinin çalışma hayatının, aile yaşamını olumsuz etkilemekte olduğu sonucuna ulaşılmıştır. Dikmen ve Madene göre ise (2015) ev işleri, çocuk bakımı ve benzeri işleri yapma zorunluluğu gibi rutin roller büyük ölçüde hala kadın tarafından üstlenilmektedir. Dolayısıyla kadın akademisyenlerin iş yaşamı ve aile yaşantıları arasında ipteki bir cambaz gibi dengeyi sağlama çabasında oldukları görülmektedir. Bu bulgunun Monroe ve diğ. (2008), Günçavdı (2017) ve Basurto-Barcia ve Ricaurte-Quijano' nun, (2017) çalışma sonuçlarıyla paralellik gösterdiği görülmüş, iş aile dengesi kurma konusunda akademisyenlerin problem yaşadıkları vurgulanmıştır. Neale ve Özkanlı'nın (2010) rektörlük ve rektör yardımcılığı yapmış kadın akademisyenlerle yürüttüğü çalışmasına göre kadın akademisyenlerin, iş ve aile dengesini ancak yönetim pozisyonlarındaki görevlerinden ayrıldıktan sonra sağlayabildikleri görülmüştür. O'Laughlin ve Bischoff(2005); Comer ve Stites-Doe' nin (2006); çalışmaları da bu bulguları desteklemekte ve erkeklere kıyasla kadınların daha çok akademik stres ve aile stresi yaşadıkları; iş ve aile dengesi konusunda daha az kurumsal destek algısına sahip oldukları ortaya çıkmıştır.

İş yaşamında sürekli mücadele ve kendini ispat etmek zorunda olan aynı zamanda çoklu rollere sahip, az zamanda çok şeyi başarması gereken kadın akademisyenlerin zorlu bir tempoda yaşamlarını sürdürmeye çalıştıkları düşünüldüğünde ortaya çıkan bir diğer tema "mucizevi bir varlık olarak kadın akademisyen" olmuştur. Çalışmaya katılan akademisyenler hem akademik anlamda hem de kişisel ve sosyal yaşamlarında başarı ve dengeyi ancak insanüstü mucizevi güçlerle sağlayabileceklerine ve bunun zorluğuna atıf yaparak kendilerini çeşitli güçleri olan masal kahramanlarına ve süper kahramanlara benzetmişlerdir. Çalışmada elde edilen temalardan diğeri de bu tema ile paralel şekilde "güçlü olması gereken biri olarak kadın akademisyen"dir. Bu iki tema da kadın akademisyen olmanın güçlü bir duruş gerektirdiği şeklinde yorumlanmaktadır.

Akademik alanda diğer sektör gruplarına oranla daha fazla kadın istihdamı görülmekle beraber, akademideki kadın akademisyenlerin de diğer sektörlerdeki kadınların sorunlarını paylaştıkları görülmektedir. Buna paralel olarak bir diğer tema da "engellenen biri olarak kadın akademisyen" ortaya çıkmıştır. Kadın akademisyenler, toplumsal cinsiyet kalıpları gereği erkek meslektaşlarına oranla daha fazla mücadele etmek ve kendilerini ispatlamak durumunda olduklarını ifade etmişlerdir. Çalışmalar kadın akademisyenlerin akademiye giriş aşamasında bir engellenme ile karşılaşmadıklarını fakat ileri süreçlerde özellikle yönetim pozisyonlarında erkek meslektaşlarının gerisinde kaldıklarını belirtmektedir (Monroe ve diğ., 2008; Small ve diğ., 2011; Munar ve diğ., 2015; Öztan ve Doğan, 2015; Xu ve diğ., 2017; Öztürk, 2017: 211). Bu anlamda bulguların stereotip kuramına uygunluk gösterdiği söylenebilir. Kadınların duygusal, merhametli ve yöneticilik vasıflarından yoksun olduğunun düşünülmesi kadın akademisyenlerin idari pozisyonlarda daha az yer almasının bir sebebi olarak değerlendirilebilir. Xu ve diğ.'nin (2017) çalışma sonuçları da turizm akademisinde işe alımda ve yönetici pozisyonlarına atanma konusunda cinsiyete göre erkeklere öncelik verildiğini göstermiştir. Ünnü ve diğ. (2014) ve Yenilmez'in (2016) çalışmasında ise karar verme mekanizmalarına katılım düzeyinin düşüklüğünün temelinde cam tavan etkisi ve toplumsal cinsiyet rollerinin beraberinde getirdiği cinsiyet eşitsizliği belirleyici etkenler olarak ortaya çıkmıştır (Ünnü ve diğ., 2014). Ayrıca bu bulgular Schein ve diğ. (1996: 34) tarafından ortaya konan "think manager-think male" (yönetici erkek olur) algısının akademide de halen geçerli olduğunu göstermektedir. 
Bir diğer tema da "uyum sağlaması gereken biri olarak kadın akademisyen" temasıdır. Kadın akademisyenler kadınsı özelliklerini bir tarafa bırakarak erkeklerin dünyasında ancak onlardan biriymiş gibi davrandıkları takdirde dikkate alınacaklarına inanmakta, içinde bulundukları sistemin kendilerini belirli kalıplara sokma çabasıyla karşı karşıya olduklarını belirtmişlerdir. Bu bulgu Suğur ve Cangöz'ün (2016: 111) çalışması ile paralellik göstermiştir. Çalışmaya katılan idari pozisyonlarda bulunan kadın akademisyenler ancak "erkekleştiklerinde" akademik yönetim mekanizmalarında başarılı olabildiklerine işaret etmişlerdir. Kloot'un (2004) çalışmasına katılmış kadın akademisyenler benzer şekilde yönetim kademesinde yer alacak kadın akademisyenlerin "yumuşak kalpli” olmamaları gerektiği düşünmektedir.

Kadın akademisyenler aynı zamanda kendilerini "üretken biri olarak kadın akademisyen", "zarif biri olarak kadın akademisyen" ve "enerjik biri olarak kadın akademisyen" olarak olumlu imgelerle de betimlemişlerdir. Bulgulanan sonuçlar Özkanlı ve Korkmaz (2000) ve Armenti ve Acker' in (2004); gerçekleştirdiği araştırma sonuçları ile örtüşmektedir. Kadın akademisyenler, akademik kariyeri yaşam boyu süren zorlu bir yol olarak algılasalar da mesleklerine karşı olumlu tutumlara sahip olup meslek seçimlerinden ötürü pişmanlık duymamaktadırlar.

Bu çalışmadan elde edilen veriler doğrultusunda sonuç olarak literatür bulguları ile örtüşecek şekilde kadın akademisyenlerin diğer iş kollarında çalışan kadınlar gibi gerek ev gerekse iş yerinde mücadele içinde oldukları ve sürekli çalışıp çabaladıkları görülmektedir. Kadın akademisyenlerin aynı zamanda çoklu görev ve sorumlulukları dolayısıyla rol çatışması yaşadıkları, özel yaşamlarından çoğu kez fedakârlık ettikleri, iş ve aile yaşamlarını dengeleme noktasında zorlandıkları, erkek meslektaşlarına oranla daha fazla çalışmak ve kendilerini ispat etmek durumunda oldukları çalışmanın önemli bulguları arasındadır. Bunlara ek olarak kadın akademisyenlerin bazı noktalarda engellendikleri ve uyum sağlamak zorunda bırakıldıkları, tüm bunlara rağmen kendilerini yine de zarif, üretken, enerjik ve güçlü olarak algıladıkları söylenebilir. Her ne kadar akademide kadın istihdamı diğer sektörlere oranla nicelik olarak fazla olsa da akademideki kadın akademisyenlerin farklı sektörlerde çalışan kadınlarla aynı şekilde toplumsal cinsiyet rolleri ve etkilerinden tamamıyla arınmamış oldukları söylenebilir. Bu noktada hizmet veren kadın, hizmet alan erkek anlayışı tartışmaya açılmalıdır. Kadınların görünmeyen emeği üzerine gerçekleştirilen çalışmalar oldukça sınırlıdır. Bu konuda yapılacak çalışmalar iş-ev ikileminde kalan kadınların sorunlarının hem tespitine hem de bu tespitten hareketle iş aile yaşamını uyumlaştırıcı politikaların üretilmesine olanak sağlayacaktır.

Çalışma sonuçları ışığında üniversitelerde kadın akademisyenlerin çalışma koşullarını iyileştirici önlemler alınması önerilebilir. Kloot (2004) çalışmasında cinsiyet sorunun yönetilebilmesi için üniversitenin her kademesinde cinsiyet eşitliğinin görünür hale gelmesi gerektiğini ve toplumsal cinsiyet farklarının üniversitelerde zenginlik yaratan bir faktör olarak kabul edilmesi gerektiğini vurgulamıştır. Sanders ve diğ.'nin (2009) gerçekleştirdikleri çalışmaları üniversitelerdeki kadın akademisyenlerin niceliğine değil kadın dostu akademik ortamların yaratılması gerektiğine odaklanılmasını önermektedir. Bu olumsuz çevrenin kadın akademisyenlerin kariyer gelişimi üzerinde olumsuz bir etkiye sahip olacağı vurgulanmıştır (Sanders ve diğ., 2009: 319). Machado Taylor ve Özkanlı'nın (2013) çalışmalarında vurguladığı gibi üniversite üst yönetiminde akademisyen kadınların temsilini artırmak adına işyerinde kadınların korunması, aile içerisinde daha aktif olan bir babalığın teşvik edilmesi ile aile-iş çatışmasını ortadan kaldırılması önerilebilir. Öte yandan üniversitelerde çocuk bakım hizmetleri (kreş ve anaokulu) gibi imkânların iyileştirilmesi ve kadın akademisyenler için izin sürelerinin artırılması gerektiği düşünülmektedir. 
Daha önce yapılmış çalışmaların bulguları pek az kadın akademisyenin bir rol modeli ya da mentorunun olduğunu ortaya koymuştur. Amerika'da yapılmış bir çalışmanın sonuçları, mentoru olan kadın akademisyenlerin yayın faaliyetlerinin arttığını ve kariyer memnuniyetlerinin yüksek olduğunu ortaya çıkarmıştır (Levinson ve diğ., 1991; Blood ve diğ., 2012). Cullen ve Luna (2006) mentorluk uygulamalarının kadın akademisyenlerin kariyer gelişimini engelleyen unsurları azaltacağını belirtmektedir. Dolayısıyla üniversitelerde başarılı kadın akademisyenler ve genç akademisyenlerin bir araya gelmeleri teşvik edilerek mentorluk (koçluk) ilişkisi sağlanması hem akademik hem de kişisel tecrübelerin aktarılması yoluyla kadın akademisyenlerin birbirini destekleyebileceği platformların oluşturulması önerilebilir.

Bu çalışmanın alanyazına bazı katkıları söz konusudur. Kavramsal açıdan bakıldığında çalışmanın en önemli katkısını şu şekilde açıklamak mümkündür. Ülkemizde kadın akademisyenlerle ilgili yapılmış çalışmalar bulunmakla birlikte bu araştırma Türkiye'de turizm alanında çalışan kadın akademisyenleri doğrudan ele alan ilk çalışmadır. Bu araştırmada elde edilmiş bulguların ulusal ve uluslararası kadın çalışanlar üzerine gerçekleştirilen çalışmaların sonuçları ile örtüştüğü görülmekle birlikte çalışmanın bizzat kadın turizm akademisyenlerinin gözünden sunulması bağlama ilişkin özgün bilgi üretilmesine olanak sağlamıştır. Metodolojik açıdan ise Türkiye'de kadınlar üzerine gerçekleştirilen araştırmalar arasında yöntem açısından bir yenilik oluşturmasıdır. Daha önce ağırlıkla nicel verilerle yapılan araştırmalara karşın bu çalışmanın metaforlar çerçevesinde toplanan verilerin analizine tabi tutulduğu bir yaklaşımı benimsemiş olması önemli bir metodolojik katkı olarak görülebilir. Üretilen bilginin ileride yeni araştırmalar ve fikirler üretmesine olanak tanıyacağına inanılmaktadır.

Her çalışmanın olduğu gibi bu çalışmada da bazı kısıtlar söz konusudur. Çalışmanın örneklemi sadece Türkiye bağlamını içermektedir. Turizm alanında çalışan kadın akademisyenleri ele alan bu çalışma sosyal bilimlerin diğer alanları, fen bilimleri vs. gibi alanlarda çalışan kadın akademisyenleri de içine alacak şekilde genişletilebilir. Özellikle erkek akademisyenlerin çoğunlukla bulunduğu mühendislik ve yer bilimleri alanlarında çalışan kadın akademisyenlerin düşüncelerinin ortaya çıkarılmasının da önemli olduğu düşünülmektedir. Bilhassa kadın akademisyenlerin kendi öykülerinden yararlanılan nitel çalışmalara ağırlık verilmesi faydalı olabilir. Kadın akademisyenlerin kendi gelecekleri için nasıl mücadele ettikleri, kariyerlerini nasıl oluşturduklarına ilişkin öykülerin sonuçları 21. yüzyılda psikolojik bir perspektifle yapılan "kadın çalışan" araştırmalarının önemli sorunlarından biri haline gelebilir. Bununla birlikte gelecekte yapılacak kültürlerarası araştırmalar alanyazına değer katacaktır.

Sonuç olarak araştırma sonucunda elde edilen bulgular dikkate alındığında ilgili alanda çalışan "kadın akademisyenlerin" tutum ve davranışları ve bunun örgütsel yansımalarının altında yatan ilişki örüntülerinin anlaşılmasına yönelik çabaların sürmesi gerekliliği ifade edilebilir.

\section{Kaynakça}

Acker, S.ve Armenti, C. (2004),'Sleepless in Academia', GenderandEducation, 16(1), ss. 3-25.

'Akademisyen Sayıları', (2018), https://istatistik.yok.gov.tr/ (30.04.2018)

Aiston, S. J. (2014),'Leading the Academy or Being Led? Hong Kong Women academics', Higher Education Research \& Development, 33(1), ss. 59-72. 
Aras, M. ve Karakiraz, A. (2013), 'Zaman Temelli İş Aile Çatışması, Düşük Başarı Hissi ve İş Tatmini İlişkisi: Doktora Yapan Araştırma Görevlileri Üzerinde Bir Araşıırma', Siyaset, Ekonomi ve Yönetim Araştırmaları Dergisi, 1(4), ss. 1-13.

Armenti, C. (2004), 'May Babies and Posttenure Babies: Maternal Decisions of Women professors', The Review of Higher Education, 27(2), ss. 211-231.

Arthur, N.,Patton, W. A.veGiancarlo, C. (2007),'International Project ParticipationbyWomenAcademics', CanadianJournalof Education, 30(1),ss. 323348.

Bagilhole, B. (1993),'How to Keep A Good Woman Down: An Investigation of the Role of Institutional Factors in The Process of Discrimination Against Women Academics', British Journal of Sociology of Education, 14(3), ss. 261-274.

Basurto-Barcia, J.veRicaurte-Quijano, C. (2017),'Women in Tourism: Gender (in)Equalities in UniversityTeachingandResearch', Anatolia,28(4),ss. 567-581.

Başarır, F.ve Sarı, M. (2015),'Kadın Akademisyenlerin "Kadın Akademisyen Olma"ya İlişkin Algılarının Metaforlar Yoluyla İncelenmesi', Journal of HigherEducationveScience/Yüksekögretim ve Bilim Dergisi, 5(1),ss. 41-51.

Belkıs, Ö. (2016),'Anneliğin Akademik Kariyer Gelişimine Etkileri Üzerine Nitel Bir Araştırma', Eğitim ve Öğretim Araştırmaları Dergisi,5, ss. 250-263.

Blood, E. A., Ullrich, N. J., Hirshfeld-Becker, D. R., Seely, E. W., Connelly, M. T., Warfield, C. A. ve Emans, S. J. (2012),'Academic Women Faculty: Are They Finding the Mentoring They Need?',Journal of Women's Health, 21(11), ss. 1201-1208.

Cullen, D. L. ve Luna, G. (1993),'Women Mentoring in Academe: Addressing the Gender Gap in Higher Education', Gender and Education, 5(2), ss. 125-137.

Comer, D. R.veStites-Doe, S. (2006),'AntecedentsandConsequences of FacultyWomen'sAcademic-Parental Role Balancing', Journal of FamilyandEconomic Issues,27(3), ss. 495-512.

Dikmen, N.ve Maden, D. (2012),'Kadın Akademisyenlerin Görünmeyen Emeği Üzerine Bir Araştırma: Ordu Üniversitesi Örneği', Sosyal ve Beşeri Bilimler Dergisi, 4(2), ss.235-250.

Doyle, C. ve Hind, P. (1998), 'Occupational Stress, Burnout and Job Status in Female Academics', Gender, Work \& Organization, 5(2), ss. 67-82.

Emeklier, B. (2011),'Uluslararası İlişkiler Disiplininde Epistemolojik Paradigma Tartışmaları: Postpozitivist Kuramlar',Bilge Strateji, 3(4), ss. 139-184.

Er, D. (2008), Modern Türkiye'de Kadın Öğretim Üyelerinin Konumuna ve Sorunlarına Sosyolojik Bir Yaklaşım, Yayınlanmış Doktora Tezi, Fırat Üniversitesi, Sosyal Bilimler Enstitüsü, Elazığ.

Forster, N. (2000),'A Case Study of Women Academics' Views on Equal Opportunities, Career Prospects and Work-Family Conflicts in a British University', Career Development International, 6(1), ss.28-38.

Fox, M. F. (1991), 'Gender, Environmental Milieu, and Productivity in Science' İçinde H. Zuckerman , J. R. Cole ve J. T. Bruer (Editörler), The Outer Circle: Women in the Scientific Community, ss. 107-119, New Haven, Yale University Press.

Ergöl, Ş., Koç, G., Eroğlu, K.ve Taşkın, L. (2012),'Türkiye'de Kadın Araştırma Görevlilerinin Ev ve İş Yaşamlarında Karşılaştıkları Güçlükler', Yükseköğretim ve Bilim Dergisi, 2(1), ss. 43-49.

Santos G. G. ve Cabral-Cardoso C. (2008), 'Work-Family Culture in Academia: A Gendered View of Work-Family Conflict and Coping Strategies', Gender in Management: An International Journal, 23(6), ss. 442 - 457.

Gupta, N.,Kemelgor, C., Fuchs, S.veEtzkowitz, H. (2005), 'TripleBurden on Women in Science: A Cross-Cultural Analysis', CurrentScience, 89(8),ss. 1382-1386.

Günçavdı, G., Göktürk, Ş., ve Bozoğlu, O. (2017), 'An InsightintoTheChallengesFacedbyAcademicWomenwithPre-School Age 
Children in Academiclife', Universal Journal of EducationalResearch, 5(6), ss: 953-959.

Güner, A. (2008), Kadının Çalışma Yaşamındaki Sorunlarına Yönelik Algıları,Yayınlanmamış Yüksek Lisans Tezi, Marmara Üniversitesi, Sosyal Bilimler Enstitüsü, İstanbul.

Günlük Seven, G. (2009),'GlassCeiling in Academic Administration inTurkey: 1990s versus 2000s', TertiaryEducationandManagement, 15(4), ss. 305-322.

Hada, Y. (2013), Womenin HigherEducation in Japan and in East Asia. Tokyo: PaperPresented at theBritish CouncilSeminarAbsentTalent: Women in AcademicLeadershipin East Asia.

Healy, G.,Özbilgin, M., ve Aliefendioğlu, H. (2005), 'AcademicEmploymentandGender: A TurkishChallenge toVerticalSexSegregation', EuropeanJournal of IndustrialRelations, 11(2),ss. 247-264.

Habertürk (2018), http://www.haberturk.com/111-devlet-universitesinin-sadece-3tanesinin-rektoru-kadin-1788441 (02.06.2018)

Hooks, B. (1994), 'Teaching to Transgress: Education As the Practice of Freedom' New York: Routledge.

Ismail, M. ve Rasdi, R. M. (2007),'Impact of networking on career development: Experience of high-flying women academics in Malaysia',Human Resource Development International, 10(2), ss. 153-168.

İrey, Ç. (2011),Türkiye Üniversitelerinde Kadın Emek Gücü: Selçuk Üniversitesi Kadın Akademisyenler Üzerine Bir Araştırma, Yayınlanmış Yüksek Lisans Tezi, Selçuk Üniversitesi, Sosyal Bilimler Enstitüsü, Konya.

Kahraman L., Kahraman, A.B., Ozansoy, N., Akıllı, H., Kekillioğlu, A. ve Özcan, A. (2014),'Nevşehir Hacı Bektaş Veli Üniversitesi Toplumsal Cinsiyet Algısı araştırması', TurkishStudies, 9(2), ss. 11-31.

Karaca, A. (2007), Kadın Yöneticilerde Kariyer Engelleri: Cam Tavan Sendromu Üzerine Uygulamalı Bir Araştırma (Bankacılık Sektörü),Yayınlanmış Yüksek Lisans Tezi, Selçuk Üniversitesi, Sosyal Bilimler Enstitüsü, Konya.

Karakuş, H. (2016),'Delik Boru: Türkiye'deki Akademisyen Kadınlar Üzerine Bir Analiz', The Journal of AcademicSocialScienceStudies, 53, ss. 533-556.

Kılıç, D.ve Öztürk, S. (2014),'Türkiye'de Kadınların İşgücüne Katılımı Önündeki Engeller ve Çözüm Yolları: Bir Ampirik Uygulama', Amme Idaresi Dergisi, 47(1), ss. 107-130.

Kloot, L. (2004), 'WomenAndLeadership in Universities: A Case Study of WomenAcademicManagers', The International Journal of PublicSector Management, 17(6), ss. 470-485.

Köle F. (2011),Mersin Üniversitesi Kadın Akademisyenlerinin Örgütlerindeki Cinsiyet Kültürüne Yönelik Algıları, Yayınlanmış Yüksek Lisans Tezi, Mersin Üniversitesi, Mersin.

Küçükşen, K.ve Kaya, Ş. D. (2016),'Yönetici Pozisyondaki Akademisyen Kadınlarda Aile-İş-Özel Yaşam Dengesi', Akademik Sosyal Araştırmalar Dergisi, 4(37), ss. 662-674.

Landis, J. R. veKoch, G. G. (1977),'An Application of HierarchicalKappa-TypeStatistics in TheAssessment of MajorityAgreementAmongMultipleObservers', Biometrics, 33(2), ss. 363-374.

Levinson, W., Kaufman, K., Clark, B. ve Tolle, S. W. (1991),'Mentors and Role Models for Women in Academic Medicine', Western Journal of Medicine, 154(4), ss. 423426.

Linehan, M.veWalsh, J. S. (1999), 'SeniorFemale International Managers: BreakingTheGlassBorder', Women in Management Review, 14(7), ss. 264-272. 
Macarie, F. C. veMoldovan, O. (2012), 'GenderDiscrimination in Management TheoreticalandEmpiricalPerspectives', TransylvanianReview of AdministrativeSciences, 35, ss. 153-172.

Machado Taylor, M. L. ve Özkanlı, Ö. (2013), 'GenderandAcademicCareers in PortugueseandTurkishHigherEducationInstitutions', EducationandScience, 38(169), ss. 346-356.

McCall. L, Liddell, M., O'Neil, J. O. ve Coman G. (2000),'Strategies to increase the Representation of Women on the Academic Staff of the Faculty of Medicine at Monash University', Higher Education, 39, ss. 131149.

Monroe, K.,Ozyurt, S., Wrigley, T., ve Alexander, A. (2008),'GenderEqualityin Academia: BadNews fromtheTrenches, Solutions',AmericanPoliticalScienceAssociation, 6, ss. 215-233.

Morley, L. (2014),'LostLeaders: Womenin The Global Academy', HigherEducationResearchand Development, 33(1), ss. 114-128.

Munar, A. M., Biran, A., Budeanu, A., Caton, K., Chambers, D., Dredge, D., ve Ram, Y. (2015), TheGenderGap in Tourism Academy: Statisticsandlndicators of GenderEquality. WhileWaitingfortheDawn,Copenhaguen: TourismEducationFutures.

Neale, J.ve Özkanlı, O. (2010),'OrganisationalBarriersForWomen in Senior Management: A Comparison of TurkishandNew ZealandUniversities', GenderandEducation, 22(5), ss. 547-563.

Nguyen, T. L. H. (2013),'BarrierstoandFacilitators of FemaleDeans' CareerAdvancement in HigherEducation: An ExploratoryStudy in Vietnam', HigherEducation, 66(1), ss. 123-138.

O'Laughlin, E. M.veBischoff, L. G. (2005),'BalancingParenthoodandAcademia: Work/FamilyStress As InfluencedbyGenderandTenureStatus', Journal of Familylssues, 26(1),ss. 79-106.

Okay, N. (2007), 'Türkiye'de ve Dünya'da Mühendislik ve Fen Bilimleri Bölümlerindeki Kadın Akademisyenlerin Mevcut Durumuna Bakış',Cumhuriyet Bilim Teknik, 289(3), ss. 1-3.

Örücü, E., Kılıç, R.ve Kılıç, T. (2007),'Cam Tavan Sendromu ve Kadınların Üst Düzey Yönetici Pozisyonuna Yükselmelerindeki Engeller: Balıkesir İli Örneği', Yönetim ve Ekonomi, 14(2), ss. 117-135.

Özkalp E. veKırel Ç. (2001),Örgütsel Davranış, Eskişehir; Anadolu Üniversitesi Eğitim, Sağlık ve Bilimsel Araştırma Çalışmaları Vakfı.

Özkanlı, Ö. (2007),'TheSituation of AcademicWomeninTurkey',EducationandScience, 32(144), ss. 59-70.

Özkanlı, Ö.ve Korkmaz, A. (2000),Kadın Akademisyenler. Ankara: Ankara Üniversitesi Siyasal Bilgiler Fakültesi Yayınları.

Özkanlı, Ö. ve White, K. (2009),'GenderandLeadership in TurkishandAustralianUniversities', EqualOpportunities International, 28(4), ss. 324-335.

Özkaplan, N. (2013),'Kadın Akademisyenler: Cam Tavanlar Hâlâ Çok Kalın!', Kadın Araştırmaları Dergisi, 12,ss. 1-23.

Özkaplan, N.ve Serdaroğlu, U. (2004),'Yönetici Kadınlar: Türk Savunma Sanayi Örneğinde Bir Analiz', Ekonomik Yaklaşım, 15(52),ss. 77-93.

Özsöz, C. (2008), 'Kültürel Feminist Teori ve Feminist Teorilere Giriş', Sosyoloji Notları, 6, ss. 51-55.

Öztan, E.ve Doğan, S. N. (2015), 'AkademininCinsiyeti: Yıldız Teknik Üniversitesi Örneği Üzerinden Üniversite ve Toplumsal Cinsiyet', Çalışma ve Toplum, 46(3), ss. 191-222. 
Öztürk, U. C. (2017),'Akademideki Topuk Sesleri: Cam Tavan Perspektifinde Göller Bölgesi ÜniversitelerininBetimsel Analizi',PESA Ulus/ararası Sosyal Araştırmalar Dergisi, 3(4), ss. 202-213.

Özyer, K.ve Azizoğlu, Ö. (2014),'İş Hayatında Kadınların Önündeki Cam Tavan Engelleri İle Algılanan Örgütsel Adalet Arasındaki İlişki',AiBÜ-iliBF Ekonomik ve Sosyal Araştırmalar Dergisi, 10(1), ss. 95-106.

Powell, G. N.veButterfield, D. A. (1994),'Investigatingthe "GlassCeiling” Phenomenon: An EmpiricalStudy of ActualPromotionsto Top Management', Academy of Management Journal, 37(1), ss. 68-86.

Poyraz, B. ve Ulusoy, S. (2013),Bilim Mühendislik ve Teknolojide Kadın Akademisyenler Ağı Ankara Üniversitesi Raporu, Ankara: Ankara Üniversitesi Bilimsel Araştırmalar Birimi.

Poyraz, B. (2013), 'Akademi Kadınların Cenneti mi? Ankara Üniversitesi Örneği',Ankara Üniversitesi Sosyal Bilimler Enstitüsü Dergisi, 4(2),ss. 1-18.

Probert, B. (2005), 'I Just Couldn'tFit it in': Gender and Unequal Outcomes in Academic Careers', Gender, Work \&Organization, 12(1), ss. 50-72.

Raburu, P. A. (2015),'Motivation of Women Academics and Balancing Family \& Career', Journal of Educational and Social Research, 5(1), ss. 359-370.

Rhoads, R. A. ve Gu, D. Y. (2012),'A Gendered Point of View on the Challenges of Women Academics in The People's Republic of China', Higher Education, 63(6), ss. 733-750.

Sabatier, M.,Carrere, M., veMangematin, V. (2006),'Profilesof AcademicActivitiesandCareers: DoesGenderMatter? An Analysis Based On French Life ScientistCVs', The Journal of Technology Transfer, 31(3),ss. 311-324.

Sabuncuoğlu, E. T. (2008),'Rol Çatışmasının ve Rol Belirsizliğinin Tükenmişlik ve İş Doyumu Üzerindeki Etkilerinin İncelenmesi',Dokuz Eylül Üniversitesi İktisadi ve Idari Bilimler Fakültesi Dergisi, 23(1), ss. 35-49

Sanders, K.,Willemsen, T. M., veMillar, C. C. (2009),'ViewsfromAbovetheGlassCeiling: DoestheAcademic InfluenceWomenProfessors' CareersandExperiences?', Sexroles, 60(5-6), ss. 301-312.

Schein, V. E.,Mueller, R., Lituchy, T., veLiu, J. (1996),'Think Manager-Think Male: A Global Phenomenon?', Journal Of Organizational Behavior, 17(1), ss. 33-41.

Schneider, B. Z.,Carden, W. Francisco, A., veJonesJr, T. O. (2011),'Women 'optingout' of Academia: At WhatCost?', Forum onPublicPolicy, 2,ss. 1-19.

SheFigures (2016), GenderinResearchandInnovation.Brussels: EuropeanCommission.

Small, J., Harris, C., Wilson, E., veAteljevic, I. (2011), 'Voices of Women: A MemoryWorkReflection on Work-Life Dis/ Harmony in TourismAcademia', Journal of Hospitality, Leisure, SportandTourismEducation, 10(1), ss. 23-36.

Suğur, S.ve Cangöz, İ. (2016), 'Üniversite Yönetiminde Kadınların Eksik Temsili Üzerinde Toplumsal Cinsiyet İlişkilerinin Rolü', Amme Idaresi Dergisi, 49(3), ss. 89-115.

Şentürk, B. (2016), ‘Çokuz Ama Yokuz: Türkiye’deki Akademisyen Kadınlar Üzerine Bir Analiz', ViraVerita E-Dergi,2, ss. 1-22.

Şentürk, B.,Ünnü, N. A. A., ve Kesken, J. (2017),'İ̧̧ Yaşamında Toplumsal Cinsiyetin Etkisi: Türkiye Üniversiteleri Örneği', Uluslararası İktisadi ve Idari Incelemeler Dergisi, 16. UiK Özel Sayısı, ss. 879-892.

Şiyve, O. Ç. (2004),'Kadın-Erkek Liderlik Tarzları ve Cam Tavan',TügiadElegans Magazin,ss. 66.

Taşkın, E.ve Çetin, A. (2012),'Kadın Yöneticilerin Cam Tavan Algısının Cam Tavanı Aşma Stratejilerine Etkisi: Bursa Örneği', Dumlupınar Üniversitesi Sosyal Bilimler Dergisi, 33,ss: 19-34.

Toffoletti, K. ve Starr, K. (2016),'Women Academics and Work-Life Balance: Gendered Discourses of Work and Care', Gender, Work \& Organization, 23(5), ss. 489-504. 
Uzun, G. (2005), Kadın ve Erkek Yöneticilerin Liderlik Davranışları Arasındaki Farklılıklar ve Bankacılık Sektöründe Uygulama, Yayınlanmamış Yüksek Lisans Tezi, Çukurova Üniversitesi, Adana.

Ünnü, N. A. A., Baybars, M., ve Kesken, J. (2014),'Türkiye’de Kadınların Üniversiteler Bağlamında Yetki ve Karar Verme Mekanizmalarına Katılımı', Dumlupınar Üniversitesi Sosyal Bilimler Dergisi, 42, ss. 121-134.

Wall, S. (2008),'Of HeadsandHearts: Womenin DoctoralEducation at A CanadianUniversity', Women'sStudies International Forum, 31, ss. 219-228.

WomeninAcademia (2017), 'Women Academia',http://www.catalyst.org/knowledge/women-academia (17.07.2018).

$\mathrm{Xu}, \mathrm{H}$. ,Wang, K., ve Ye, T. (2017),'Women'sAwareness of Genderlssues in ChineseTourismAcademia', Anatolia, 28(4), ss. 553-566.

Yenilmez, M. I. (2016), 'Womenin Academia in Turkey: ChallengesandOpportunities', Journal of AdministrativeSciences, 14(28), ss. 289311.

Yıldııım, A. ve Şimşek, H. (2008), Sosyal Bilimlerde Nitel Araştırma Yöntemleri,Ankara: Seçkin Yayıncılık.

Yılmaz, G. A. (2017),'Marmara Üniversitesi'nde Kadının Yeri',Marmara Üniversitesi Kadın ve Toplumsal Cinsiyet Araştırmaları Dergisi, 1(1), ss. 1-15. 